\title{
Two-Dimensional Animation and Students' Achievement in Mathematical Economics: Implications for Science Teaching
}

\author{
Jovita C. Ejimonye ${ }^{1}$, Christian S. Ugwuanyi ${ }^{2, *}$, Chinedu I.O. Okeke ${ }^{3} \&$ Mercy N. Nwoye ${ }^{4}$ \\ ${ }^{l}$ Department of Social Science Education, Faculty of Education, University of Nigeria, Nsukka. \\ ${ }^{2}$ Postdoctoral fellow, School of Education Studies, Faculty of Education, University of the Free State, Bloemfontein, 9300, Sou th Africa. \\ ORCID: 0000-0003-2174-3674
}

${ }^{3}$ Host, Professor and Head, School of Education Studies, Faculty of Education, University of the Free State, Bloemfontein, 9300, South Africa. ORCID: 0000-0003-3046-5266

${ }^{4}$ Department of Science Education, Faculty of Education, University of Nigeria, Nsukka.

\begin{abstract}
The twenty-first-century classroom comes with changes in instructional delivery. This has demanded a paradigm shift on pedagogical practices. In the Nigerian context, literature is scarce on the impact of two-dimensional (2D) animation on students' achievement. Thus, this study explored the impact of 2D animation technique on students' achievement in mathematical contents of Economics. Non-equivalent groups quasi-experimental design was adopted for the study with a sample size of 162 senior secondary 2 Economics students. The sample is made up of 80 male students and 82 female students drawn from four co-educational secondary schools in Enugu metropolis, Enugu State. Economics Achievement Test (EAT) was used for data collection. An internal consistency reliability coefficient of the items of the EAT was obtained to be 0.79 using Kudder-Richardson's formula 20. Data collected were analysed using mean and analysis of covariance. The results showed that students taught the mathematical contents of Economics with two- dimensional animation technique had significantly higher post-test and follow-up mean achievement scores than those exposed to the conventional method. Thus, the 2D animation technique impacted positively on students' achievement in mathematical contents of economics. This finding has implication for science teaching meaning that $2 \mathrm{D}$ can equally be applied in the teaching of mathematically related science subjects such as physics and chemistry. It was recommended among others that 2D animation technique should be used in teaching economics in secondary schools.
\end{abstract}

Keywords:Impact, Two-Dimensional Animation Technique, Students' Achievement, Mathematical contents of Economics

\section{INTRODUCTION}

Poor achievement of Economics students in both internal and external examinations has become a source of worry to economics educators and parents at large (Ejimonye et al., 2020). The evidence of this poor achievement in Economics is seen in WASSE Chief Examiner's Report identified that the students' weaknesses are: poor graphical representations to economic analysis and simple calculations, use of wrong terminologies, failure to expatiate points, among others (West African Examinations' Council [WAEC], 2013, 2015, 2016, 2017 \& 2018). For instance, from the overall WAEC statistical report of the performance of Economics students in 2013, 2014 and 2015 in Nigeria, the percentage of Economics students that scored credit and above in 2013 is $46.17 \%, 2014$ is $26.65 \%$ and 2015 is $20.02 \%$. This implies that poor achievement of Economics students is increasing annually despite the instructional techniques used by Economics teachers. Mathematical contents of economics may be a contributing factor to students' poor performance in the subject. In collaboration with this, Ejimonye et al. (2017) found that poor background of students in Mathematics made them afraid of quantitative Economics concepts.

Quantitative Economics is concerned with a hypothesis, a tentative explanation of solutions to an abstract representation of real-world situation and problems (Umar, 2012). Quantitative Economics uses a range of complex mathematics and statistical procedures to analyse economics phenomena (Hall, 2016). It represents a systematic attempt to set theoretical hypotheses about economic reality against empirical evidence produced by observing that reality. The emphasis in quantitative Economics is always on hypothesis formation and testing. Quantitative Economics lends empirical support to economic theories which are generally expressed in quantitative terms (Hall, 2016). Quantitative Economics concepts in senior secondary school curriculum include; tools

\footnotetext{
* Corresponding author.

Email:Ugwuanyics@ufs.ac.za
} 
of Economic analysis, concept of demand, concept of supply, production possibility curve, costs concepts, revenue concepts, balance of payment, elasticity of demand and supply, national income accounting, among others (National Educational Research and Development Council [NERDC], 2008). These contents involve tables, graph and equations that explain the economic situation in a society. Some students avoid learning these quantitative Economics concepts because of their mathematical nature (Dawson, 2013).Quantitative Economics concepts are very needful in resource allocation and effective utilization of limited resources. Teaching and learning of quantitative contents demand quantitative ability by the teachers and students, respectively (Eneogu et al., 2019).

There are downward trends in quantitative interest among students during their course in secondary schools (Frenzel et al., 2010;Leder, 2015; Stoehr, 2016). These findings indicated that many students are afraid of Economics because they have not mastered the quantitative aspects and therefore dodge quantitative questions. Students' acquisition of quantitative skills is very important to enhance their achievement in Economics. This situation calls for new instructional techniques that may enhance students interest vis-à-vis their achievement in economics. Instructional techniques are activities used to engage learners in the learning process (Persaud, 2018). It shows that these activities will help the learners to be active participants in the learning process. Many types of instructional techniques like lecture method, cooperative learning technique, questioning technique, among others are used to engage learners in activities such as reading, listening, collecting, thinking, collaborating and doing (Khalil \&Elkhidar, 2016). Furthermore, some of these instructional techniques cannot make learning to be interactive and facilitating, especially in teaching and learning of problemsolving contents like quantitative Economics concepts. There are many ways learning takes place, some learn best by seeing and hearing, reflecting and acting, reasoning logically and intuitively, analyzing and visualizing (Supalak, 2016).Since the world is going digital and technological, it will be relevant to adopt the innovative technique in instructional delivery that is technological.Since the invention of computer devices, technological innovative techniques emerged to alleviate some of the problems of lecture instructional technique but some teachers are ineffective in using them (Kim, 2016). Such innovative techniques include PowerPoint technique, 2D animation technique, multimedia technique, video conferencing technique, among others. Among these innovative techniques, 2D animation was explored by the researchers due to the dearth of literature on its impact on students' achievement in the Nigerian context.

Two Dimensional Animation technique is a type of technique that could attractively facilitate learning by engaging the students during the teaching and learning process. It is the art of creating movement in a two-dimensional space (Fitzgerald,
2018). Operationally, 2D animation is a design that deals with the movement of an inanimate object, diagram or image in an $\mathrm{x}$ and $\mathrm{y}$ environment to transfer knowledge to the learners. 2D animation is the art of creating movement in a twodimensional space. 2D animation is based on x-axis and $y$ axis and the justification of $2 \mathrm{D}$ animation in this study is that it is suitable for graphical presentations. 2D animation is more like cartoon and parents use it to educate their children at home. 2D animation is designed by moving pictures within a two-dimensional environment and it works when consecutive images (or "frames) simulate motion because of slight alterations to each image.

\subsection{Theoretical background of the study}

This studyis based on the theoretical framework of Richard Mayer's(1947) cognitive theory of multimedia learning. The theory states that learning becomes effective when it comes from words and pictures than words alone. This implies that students learn more deeply from sounds and images. Mayer stipulated the three assumptions that auditory and visual channels are important for processing information; each channel has a limited capacity and learning is an active process of filtering, selecting, organizing and integrating information based upon prior knowledge. This theory assumes that auditory and visual processes have influence on sensory, working and long term memory. This theory is related to the present study in that two-dimensional animation technique consists of both visual and audio channel which can help the students to understand abstract concepts like quantitative Economics. Moreover, when two-dimensional animation is employed in the teaching and learning process, students can use their sensory memory which is short term memory to observe the skills involve in solving quantitative Economics concepts and process the information he/she has observed to create mental constructing and implement the acquired skills to solve quantitative Economics concepts. This theory has been successfully utilised by Ejimonye et al. (2020), Hamzat et al. (2017) and Edo (2017) to carry out similar studies.

\subsection{Literature Review}

Several studies have explored the effectiveness of computer animation on students' achievement as well as motivation to learn.Ugwuanyi et al (2020) found that animated powerpoint presentation (PPT) significantly enhanced the achievement of students in physics than the non-animated PPT presentation.Ejimonye et al. (2020) found that 2D animation technique proved to be significantly effective in enhancing students' motivation in quantitative contents of economics.Ugwuanyi et al. (2019) found that flipped classroom instructional technology was effective in enhancingthe achievement of physics students at both posttest and follow-up measurements.Ugwuanyi et al. (2019) 
found that powerpoint presentation had a significant effect on students' achievement in physics and mathematics. Ezza et al. (2019) found that instructional technology could significantly enhance learners' composing skills. Ruzicka and Milova (2019) found that the use of video analysis in providing feedback has a positive effect on the process of downhill skiing skills acquisition. Anigbo and Orie (2018) revealed that the experimental group taught with Microsoft PowerPoint Instruction Strategy (MSPPIS) obtained a higher mean achievement score than the control group in the post COSAT but the difference was not significant.

Hamzat et al. (2017) carried out a study on the effect of computer animation instructional package on students' achievement in practical Biology in Ilorin, Nigeria. The result revealed that the students in the experimental group who were exposed to the package had higher achievement scores than the students in the control group who were taught without the package. Edo (2017) carried out a study on the impact of computer animation learning on students' academic performance in AkwaIbom State College of Education. Gambari et al. (2014) conducted a study on the effectiveness of computer animation and geometrical instructional model on Mathematics achievement and retention among junior secondary school students in Minna, Nigeria. The result indicated that there was a significant difference in the mean achievement scores of students taught using computer animation was higher than those taught using the geometrical instructional model. Falode et al. (2016) found that students taught Agricultural Science through computer animation instructional package performed better than their counterparts taught the same concept with the lecture method.Etimet al. (2016) found that computer animation learning course wave had a positive effect on student's academic performance.Students taught Business Studies with slowmotion had a mean score than those taught with the expository method. Islam et al. (2014) researched child education through animation: an experimental study in Dhaka, Bangladesh.The finding of this study revealed that animated materials are exclusively high to improve students' learning skills and it will be effective for quick learners.

Based on the foregoing, it can be deciphered that none of the studies above looked at the impact of $2 \mathrm{D}$ animation technique on students' achievement in mathematical contents of economics both in Nigeria and beyond. Furthermore, students' performance in Economics in West African Secondary School Certificate Examination, according to Chief Examiner's Report recorded for many years proved that the poor performance is attributed to lack of basic mathematical background, inadequate skills to draw and explain tables and graphs, among others. These gaps in literature constituted the problem which the researchers sought a solution to in this study. Thus, the present study determined the impact of $2 \mathrm{D}$ animation technique on students' achievement in mathematical contents of economics in Enugu Metropolis, Nigeria.

\subsection{Objectives of the Study}

The following objectives were sought for the study.

1. Determine the impact of $2 \mathrm{D}$ animation technique on students' achievement in mathematical contents of economics at the posttest

2. Determine the impact of $2 \mathrm{D}$ animation technique on students' achievement in mathematical contents of economics at the follow-up measure.

\subsection{Hypotheses}

The following hypotheses were tested at $5 \%$ probability levels

Ho1: There is no significant impact of 2D animation technique on students' achievement in mathematical contents of economics at the posttest.

Ho2: There is no significant impact of 2D animation technique on students' achievement in mathematical contents of economics at the follow-up measure.

\section{METHODS}

\subsection{Ethical Considerations}

Research Ethics Committee of the Faculty of Education, University of Nigeria approved this study. The researchers strictly followed the ethical standard specifications of the American Psychological Association. Students who participated in this study provided informed assent.

\subsection{Design of the Study}

Non-equivalent groups quasi-experimental design was adopted by the researchers for the study.

\subsection{Participants}

A total of 162 (80 males and 82 females) in Enugu Metropolis, Enugu State, Nigeria were used as participants. Accuracy of the sample size was ensured using G-Power, version 3.1 which gave 0.79 . 


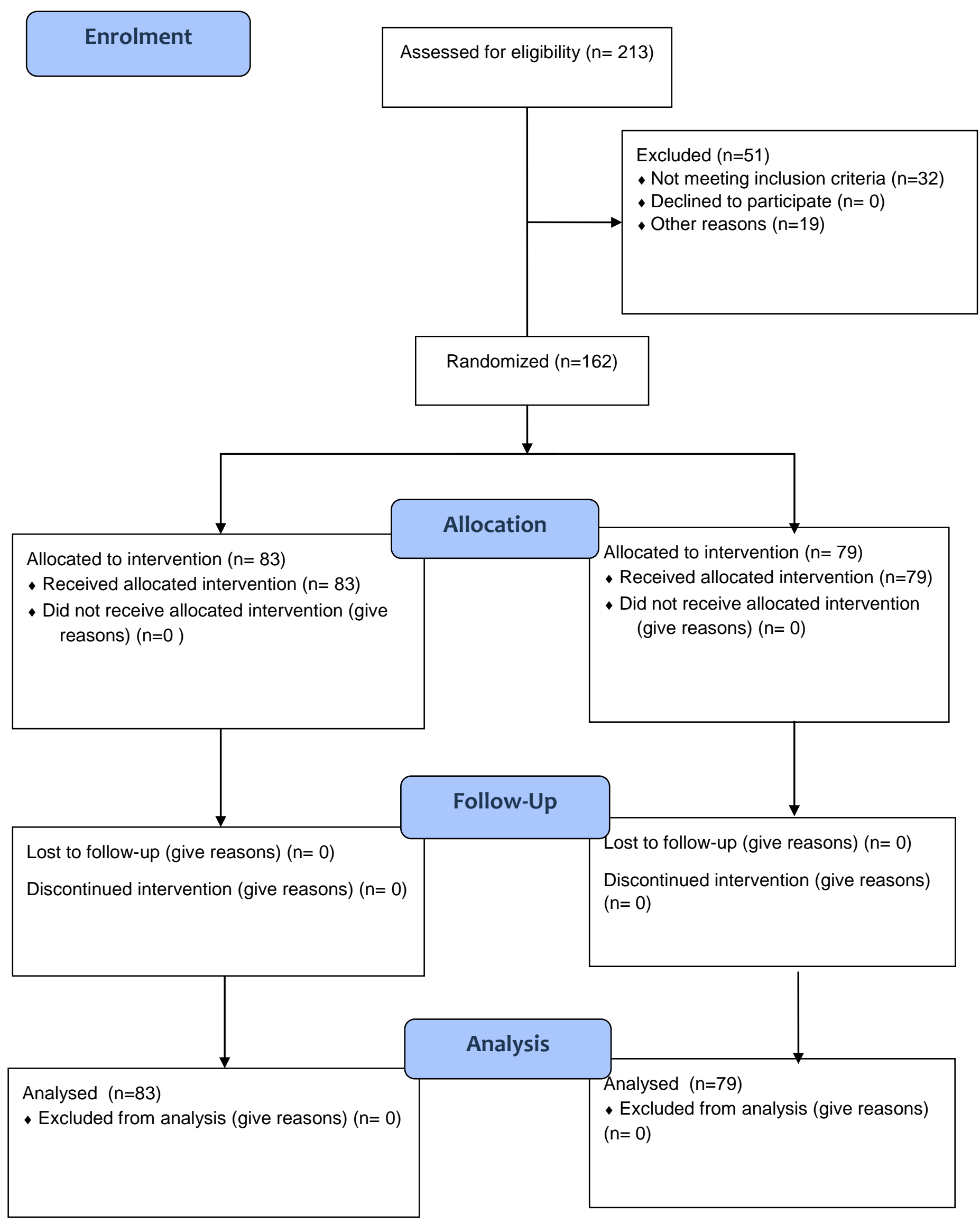

Figure1: Flow Diagram of the Sampled Participants 


\subsection{Measure}

Economics Achievement Test (EAT) was used for data collection. The EAT is made up of section A and section B. Section A contains personal information of the respondents while section B contains 50 items questions. The 50 multiplechoice items of EAT were developed by the researcher using a test blueprint. The EAT was used to evaluate the learning outcome (achievement) of senior secondary 2 Economics students both before and after the experimental treatment.

Five quantitative Economics concepts were selected from senior secondary 2 scheme of work for the development of 50 multiple choice items questions which the option responses are from A to D. The contents are as follows: Concept of demand, Concept of supply, Production possibility curve, Concept of cost and Concept of revenue. These topics are chosen because they have mathematical components that scare young Economics students. Levels of the cognitive domain of the Bloom Taxonomy was a guide in developing the EAT to make sure that the different and important ability levels will be tested and properly covered and reflected in the questions. The weighting of each topic defines the number of multiplechoice questions that were drawn from it and the number of questions from each topic is as follows: Demand is 12 questions, Supply is 12 questions, Production possibility curve is 6 questions, Cost is 9 questions and Revenue is 11 questions. Each correct answer was scored 1 mark making a total of 50 marks. EAT was content and face validated by test experts and as well trial tested to determine the internal consistency reliability of its items. An internal consistency reliability coefficient of the items of the EAT was obtained to be 0.79 using Kudder-Richardson's formula 20.

Two-dimensional animation technique movies were designed and developed by the researcher using software like Powtoon, Microsoft Word and Microsoft PowerPoint. The design was made by creating storyboards that explain the quantitative Economics concepts with characters.

\subsection{Procedure}

The following procedure was used to carry out the quasiexperimental study. Firstly, the researcher met the principals of the schools involved in the study area and sought their permission and co-operation to enable her to incorporate her research programme into the school programme for the term to avoid interrupting the school time table. Through the help of the principals, the researcher contacted the senior secondary 2 Economic teachers in the schools involved. The researcher introduced herself to them and discussed with them the skills involved in using two-dimensional animation technique and what it entails. The researcher trained the teachers on how to use the two-dimensional technique in the classroom setting in each of the sampled schools and at a convenient time. The training session lasted for four days for the experimental group. Each day was devoted to training the teachers in each of the schools since all of them cannot come together.

During the training session, the four Economics teachers for the experimental group and control group who were the research assistants were given the lesson plan already prepared for the study. The researcher explained in detail to them how to use two-dimensional animation technique during teaching and learning processes. The researcher also instructed them on how to use the video during the teaching and learning process. The researcher instructed the assistants on the importance of pause during the period the video will be displayed to carry all the students along. The researcher also trained the teachers on how to apply student-teacher interaction when the video will be paused.

Before the experiment commences, the research assistants administered EAT to the students. The research assistants collected the pre-test, marked, recorded and handed them over to the researcher for further use. After that, the experiment commenced. The control group was taught with a conventional method with explanation while the experimental group was taught with two-dimensional animation instructional technique with students - teacher interaction when the video is paused. The period of teaching in each of the groups was for four weeks. The same topics were used in four intact classes but with different techniques. The topics that were treated in the four weeks are as follows: Week 1: Concept of Demand; Week 2: Concept of Supply; Week 3: Production Possibility Curve; Week 4: Concept of cost and Revenue. In teaching each of the topics mentioned above using the two-dimensional technique, the teacher adopted the following instructional procedure:

Step 1. Introduction and identification of previous knowledge: The teacher tested the entry behaviour of the students by asking them questions on the basis of what she presented for the day.

Step 2. Explanation of two-dimensional technique: The teacher explained to the students the teaching technique she will use in the classroom. She informed them that there will be a video on the quantitative Economics concepts she will present. She also informed them that they will be attentive to the video to enable them to view and listen to the explanation from the audio. They are also informed to have written materials and pen to write down important ideas and facts from the viewing. She explained to them about students- teacher interaction section where there will be a pause after the viewing; that it is a section the teacher will explain certain points to them and they are free to ask questions for more clarification on what they have viewed. 
International Journal of Engineering Research and Technology. ISSN 0974-3154, Volume 13, Number 6 (2020), pp. 1220-1230

(C) International Research Publication House. https://dx.doi.org/10.37624/IJERT/13.6.2020.1220-1230

Step 3. Commencement of the viewing: The teacher switched on the computer and the projector to commence the viewing. The viewing lasted for some minutes. The teacher moves around the classroom to make sure that every student is attentive and watching the viewing. She ensured that the arrangement of the classroom was suitable for every student and they are seeing the projector screen.

Step 4. Students - Teacher interactions: The teacher paused the video in between for students- teacher interaction section to know whether the knowledge is transferred or not. She explained what the students viewed and allow the students to ask questions and made their input on what they have viewed. After that, she allowed the students to write down their notes. The teacher played and replayed the video twice to carry everybody along.

Step 5: Evaluation: After the viewing, the teacher displayed evaluation exercise on each topic and ask students questions. The students answered in various ways. The students that got the best answer were rewarded.
On the other hand, lecture instructional technique was used in teaching the control group. After the teaching that lasted for four weeks for the two groups, the research assistants administered the EST as post-test. At the end of the post-test, students' scripts were collected by the research assistants, marked, scored, recorded and handed over to the researcher for data analysis. The scores obtained from the groups (experimental and control group) were compared and used to address the research questions and hypotheses.

\subsection{Data Analysis}

The effectiveness of 2D animation technique in enhancing students' achievement in mathematical contents of economics was determined using analysis of covariance (ANCOVA). The effect size of the intervention was reported using Partial Eta squared. The assumption of the homogeneity of variance was determined using Leven's test of equality of variance $(F=.958, p=.460)$. The analysis was done using statistical package for social sciences version 18.0.
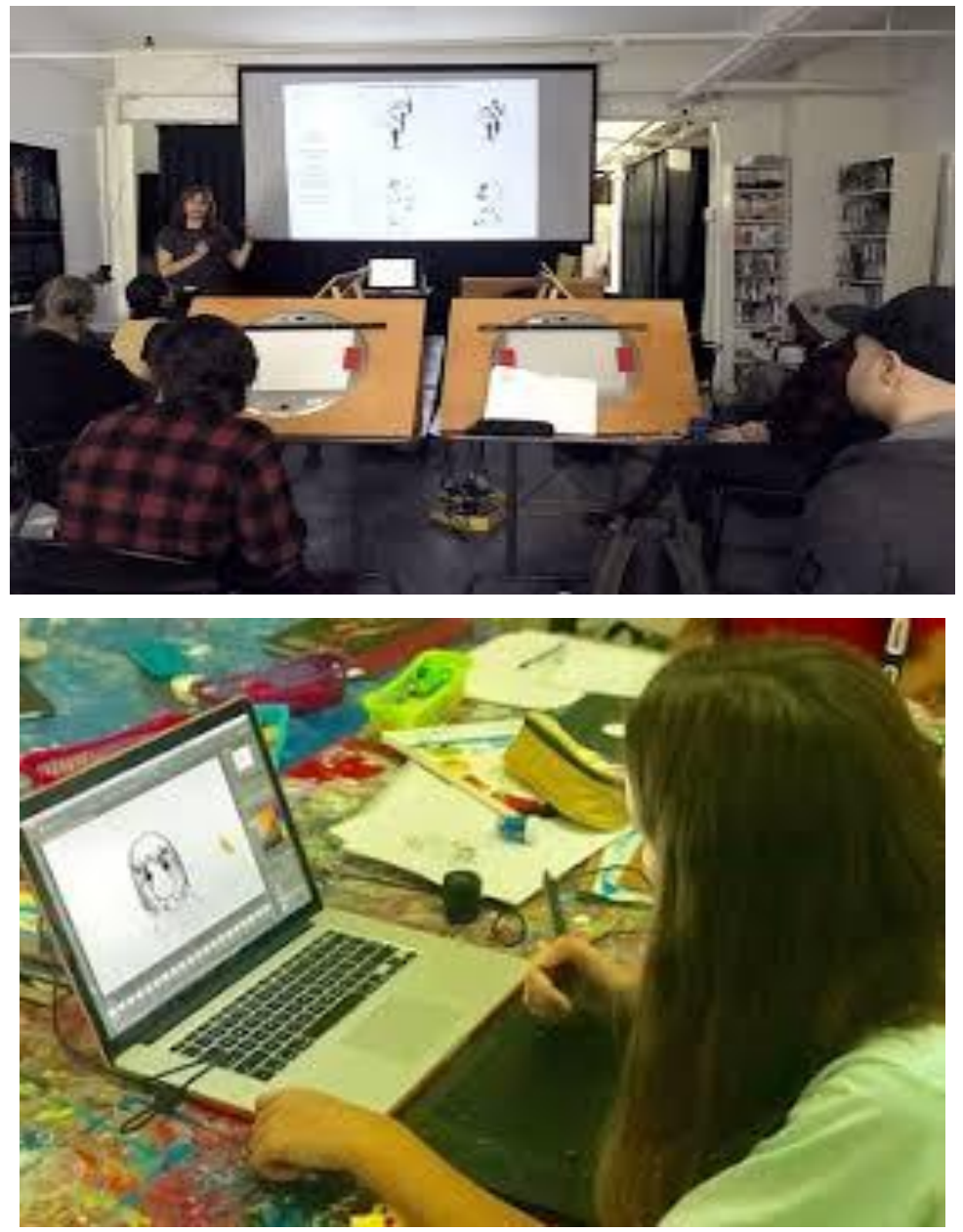

Figure 2: Class session with 2D animation software 


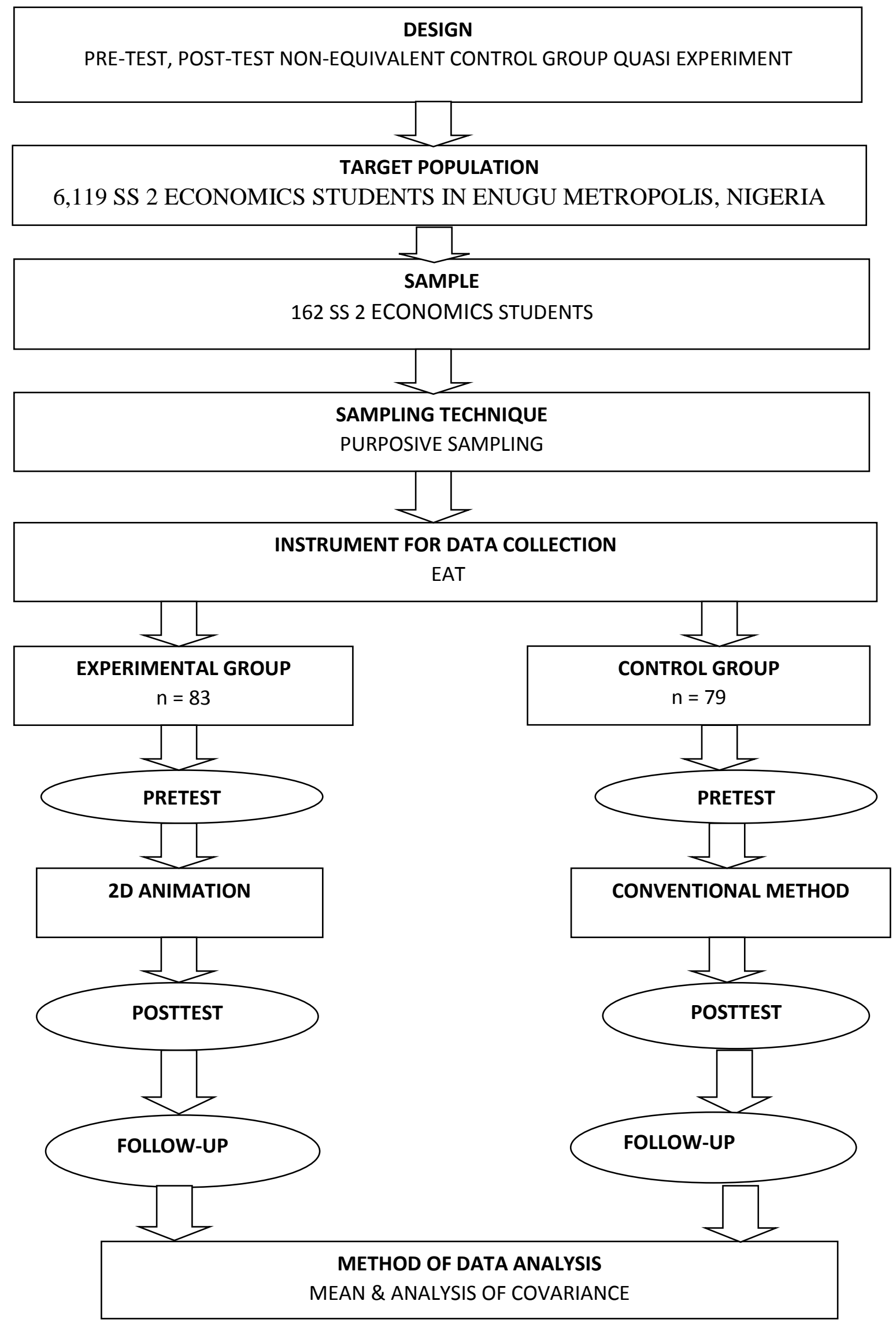

Figure 3: Schematic Representation of the Methods 
International Journal of Engineering Research and Technology. ISSN 0974-3154, Volume 13, Number 6 (2020), pp. 1220-1230

(C) International Research Publication House. https://dx.doi.org/10.37624/IJERT/13.6.2020.1220-1230

\section{RESULTS}

Table 1: Analysis of covariance of the effect of 2D animation technique on students' achievement in mathematical contents of Economics

\begin{tabular}{|c|c|c|c|c|c|c|c|}
\hline Time & Group & Mean (SD) & $\mathrm{F}$ & $\mathrm{p}$ & $y^{2}$ & $\Delta \mathrm{R}^{2}$ & $95 \% \mathrm{CI}$ \\
\hline \multirow{3}{*}{1 Pre-test } & Experimental & $17.49(5.71)$ & & & & & \\
\hline & Control & $17.51(5.58)$ & 3.216 & .075 & .013 & .015 & $1.65,3.34$ \\
\hline & Experimental & $30.24(3.85)$ & & & & & \\
\hline 2 Post-test & Control & $19.79(4.24)$ & 284.221 & $<.050$ & .644 & .686 & $254.45,321.98$ \\
\hline \multirow[t]{2}{*}{3 Follow-up } & Experimental & $31.07(3.23)$ & 287.834 & $<.050$ & .702 & & \\
\hline & Control & $19.03(8.81)$ & & & & .724 & $254.02,323.67$ \\
\hline
\end{tabular}

Mean $(S D)=$ Mean (Standard Deviation), $p=$ probability value, CI - Confidence Interval, $\eta^{2}-$ effect size, $\Delta R^{2}=$ Adjusted $R^{2}$

Table 1 reveals that there was no significant difference in the mean achievement scores of students in the experimental and control groups as measured EAT, $F(1,157)=3.216, p=.075$, $\mathrm{y}^{2}=.013, \Delta \mathrm{R}^{2}=.015$. At the posttest and follow-up measures, the impact of 2D animation technique on students' achievement in mathematical contents of economics was significant, $F(1,157)=284.221, p<.050, \mathrm{n}^{2}=.644, \Delta \mathrm{R}^{2}=$ .686 ; and $F(1,157)=287.834, p<.050, \mathrm{y}^{2}=.702, \Delta \mathrm{R}^{2}=$ .724 .
The effect sizes of 0.644 and 0.702 showed that 64.4 percent and 70.2 percent variations in students' achievement in mathematical contents of economics are as a result of their exposure to 2D animation technique. This implies that the 2D animation technique had a significant impact on students' achievement in mathematical contents of economics. Figure 4 shows the bar chart representation of the mean achievement scores of the experimental and control groups students at the pretest, posttest and follow-up measures.

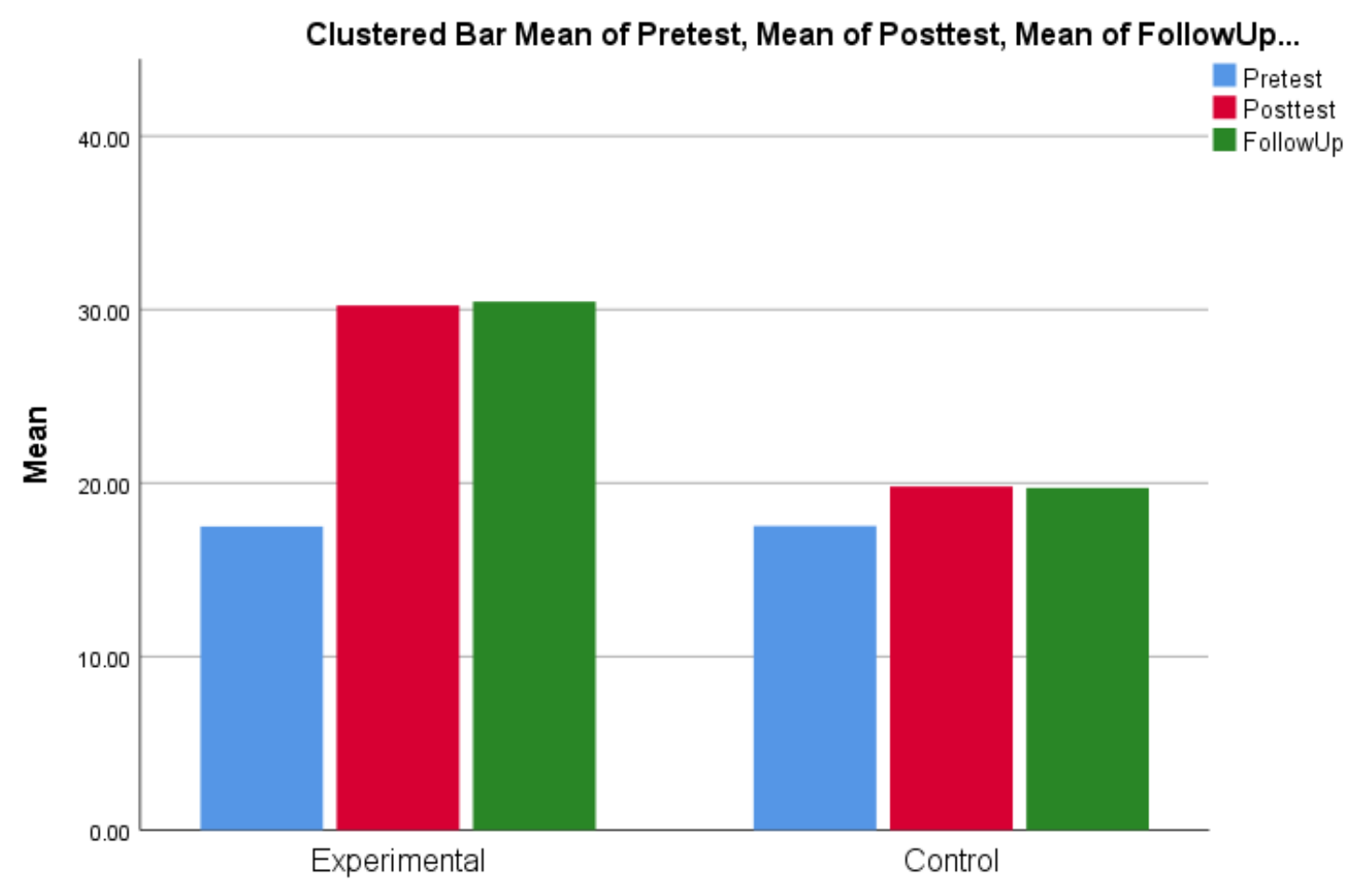

Treatment

Figure 4: Graph of the pretest, posttest, and follow-up mean achievement scores of the participants in experimental and control groups 


\section{DISCUSSION OF THE FINDINGS}

This study sought the impact of $2 \mathrm{D}$ animation technique on the students' achievement in mathematical contents of economics. The findings revealed that students taught mathematical contents of Economics using 2D animation technique had a higher post-test and follow-up mean achievement scores than those taught using the conventional method. The mean differences between the two groups were statistically significant. Based on the above, mathematical contents of economics can be demystified with the use of 2D animation technique. Computer animation technique was proved to be effective in science subject that contains mathematics concepts, hence, it has also been proved efficacious in the mathematical contents of Economics as seen in the findings of this study. It encourages self-dependency among students and increases their confidence level in learning. The moving text, objects, drawings and computergenerated images make the learning to be more interactive during classroom activities. The innovative nature of the $2 \mathrm{D}$ animation technique makes students practice and learn often and this improved their achievement. The findings of this study are in line with the findings of Ezzaet al.(2019), Ruzicka and Milova (2019), Ugwuanyi et al (2020), Ugwuanyi et al. (2019), Ugwuanyi et al. (2019), Ejimonye et al. (2020), Anigbo and Orie (2018), Edo (2017), Hamzat et al. (2017), Falode et al. (2016).

Ezza et al. (2019) found that instructional technology could significantly enhance learners' composing skills. Ruzicka and Milova (2019) found that the use of video analysis in providing feedback has a positive effect on the process of downhill skiing skills acquisition. Ugwuanyi et al (2020) found that animated powerpoint presentation (PPT) significantly enhanced the achievement of students in physics than the non-animated PPT presentation.Ejimonye et al. (2020) found that 2D animation technique proved to be significantly effective in enhancing students' motivation in quantitative contents of economics.Ugwuanyi et al. (2019) found that flipped classroom instructional technology was effective in enhancingthe achievement of physics students at both post-test and follow-up measurements.Ugwuanyi et al. (2019) found that powerpoint presentation had a significant effect on students' achievement in physics and mathematics. Anigbo and Orie (2018) revealed that the experimental group taught with Microsoft PowerPoint Instruction Strategy (MSPPIS) obtained a higher mean achievement score than the control group in the post COSAT but the difference was not significant. Hamzat et al. (2017) found that the students in the experimental group who were exposed to the package had higher achievement scores than the students in the control group who were taught without the package. Edo (2017) found that computer animation learning course wave had a positive effect on student's academic performance. Gambari et al. (2014) found that there was a significant difference in the mean achievement scores of students taught using computer animation was higher than those taught using the geometrical instructional model. Falode et al. (2016) found that students taught Agricultural Science through computer animation instructional package performed better than their counterparts taught the same concept with the lecture
method.Etimet al. (2016) assessed the use of educational animation and academic performance of Business Studies students in Akwalbom State and found that students taught Business Studies with slow-motion had a mean score than those taught with the expository method.

\section{Implication to Science Teaching}

These findings have implication for science teaching in Nigerian secondary schools. Computer animation technique has been proven to be effective in science subject that contains mathematics concepts such as physics and chemistry. This implies that the adoption of 2D animation technique in the teaching of physics and chemistry subjects will produce an enhanced academic achievement of students in those subjects.

\section{CONCLUSION AND RECOMMENDATIONS}

This study has empirically determined the impact of $2 \mathrm{D}$ animation technique in enhancing the achievement of students in mathematical contents of economics. The finding revealed that 2D animation technique significantly enhanced the achievement of students in mathematical contents of economics more than the conventional lecture method of teaching. The impact of 2D animation technique has necessitated the inclusion of technological pedagogy into the education system to bring into the classroom the practical way of disjointing the difficulty in understanding the abstract contents of Economics during learning. Thus, the researchers recommended that;

1. Teachers should be encouraged to use the twodimensional technique in teaching and learning process to enhance the achievement of students in mathematical contents of economics in particular and economics in general.

2. Students should be guided properly to value the opportunity offered by animation technique such as engaging them in the independent study both within and outside the classroom to comprehend mathematical contents of Economics.

\section{REFERENCES}

[1] Anigbo, L. C \& Orie, M. J. (2018). Effect of powerpoint instruction on students' academic achievement in computer science (database management system) in Colleges of Education in Rivers State. Computer Engineering and Intelligent Systems, 9(1). www.iiste.org

[2] Dawson (2013). Mathematics and Culture in Micronesis. The structure and function of a capacity building project. Mathematics Education Research Journal, 25, 43 - 56

[3] Edo, E. E. (2017). Impact of Computer Animation Learning on students' academic performance in Akwa Ibom College of Education, AFAHA, NSIT . Multidisciplinary Journal of Research Development, 2 (26) , 1596-974X . 
[4] Ejimonye, J.C., Eneogu, N., D \& Ugwuanyi, C.S . (2017). Analysis of student's perception of Mathematical contents of Economics that are difficult for sustainable teaching and learning of Economics in secondary schools in Enugu Urban. International Journal of studies in Education, 15 (1), 149 - 162.

[5] Ejimonye, J.C., Onuoha, J.C., Ugwuanyi, C.S., Eneogu, N.D., Ugwuanyi, B.E \& Ogbuehu, S.N (2020). Effectiveness of Two-Dimensional Animation Technique in Enhancing Students' Motivation in Quantitative Economics Concepts. International Journal of Future Generation Communication and Networking (IJFGCN), 13(1):27-38.

[6] Eneogu, N.D, Ezegbe, B.N, Ugwuanyi, B.E, Ejimonye, J.C, Idika, E.O \& Obiorah, N.J. (2019).

[7] Effectiveness of student team achievement division and team accelerated instruction on students' engagement in secondary school quantitative Economics concepts. Journal of Engineering and Applied Sciences, 14 (5), 8921 -8928.

[8] Etim, P.J, Itighise, A.E \& Ema, I.B. (2016). Use of Educational Animation and Academic Performance of Business Studies Students in Akwa Ibom State. International Journal of Education , 4 (8) , 1948-547.

[9] Ezza, E-S., Alhuqail, E. \& Elhussain, S. (2019). Technology-based instructional intervention into an EFL writing classroom. Cypriot Journal of Educational Science, 14(4), 507-519. https://doi.org/10.18844/cjes.v11i4.3904.

[10] Federal Ministry of Education. (2008). National Secondary School Curriculum. Abuja: NERDC.

[11] Fitzgerald, R. (2018). What is 3D animation? College of digital art and animation.www.cgspectrum.edu.au. retrieved $16^{\text {th }}$ of September, 2019.

[12] Frenzel, A. C., Goetz, T., Pekrun, R., \& Watt, H.M. (2010). Development of Mathematics interest in Adolescence: Influences of Gender, Family and School context. Journal of Research on Adolescence, 20(2), 507-537. doi:10.1111/j.1532-7795-2010.00645.x.

[13] Gambari, A. I, Falode, C. O. \& Adegbenro, D. A. (2014). Effectiveness of computer animation and geometrical instructional model on mathematics achievement and retention among junior secondary school students . European Journal of Science and Mathematics Education,1 (2), 157 -171

[14] Hall, S. (2016). Methods of quantitative Economics. www.ehow.com/facts. retrieved $10^{\text {th }}$ of November, 2019.

[15] Hamzat, A, Bello, G \& Abimbola, I.O. (2017). Effects of computer animation instructional package on students' achievement in practical biology . Cypriot Journal of Educational Sciences ,4 (12) , 218 -227.

[16] Islam, M.B, Ahmed, A, Islam, M.K \& Samsuddin, A. K. (2014). Child Education Through Animation: An
Experimental Study . International Journal of Computer Graphics \& Animation (IJCGA), 4 (4) , 213 -227.

[17] Khalil, M.K \& Elkhidar, I.A. (2016). Applying learning theories and instructional design models fro effective instruction. Journal of Advances in Psycchology Education, 40(2), 147 - 156.

[18] Kim. E. (2016). Three Reasons why some Teachers STILL aren't embracing the use of Technology in the classroom [web log post]: Retrieved from https://blog.esparklearning.com/

[19] Leder, G. (2015). Gender and mathematics Education Revisited. The proceedings of the 12th International Congress on Mathematical Education (pp. 145-170). Switzerland: Springer, Cham.

[20] Ruzicka, I. \& Milova, J. (2019). Increasing the efficiency of motor learning with the help of video analysis. Cypriot Journal of Educational Science, 14(4), 723-730. https://doi.org/10.18844/cjes.v11i4.1217

[21] Stoehr, K. (2016). Mathematics Anxiety. Journal of Teacher Education, 68(1), 69-84.

[22] Supalak, N. (2016). Comparative exploration of learning styles and teaching techniques between thai and vietnamese EFL students and instructors. Journal of Language and Culture Education, 4(3), 1339 - 4584.

[23] Ugwuanyi, C.S., Nduji, C.C., Gana, C.S., Nwajiuba, C.A., Ene, C.U., Okeke, A.O., Eseadi, C., \& Okeke, C.F. (2019). Effectiveness of Flipped Classroom Instructional Technology Model in Enhancing Students' Achievement in Physics. International Journal of $u$ - and e-Service, Science and Technology, 12(4), 3746.http://article.nadiapub.com/IJUNESST/vol12_no4/4. html

[24] Ugwuanyi, C.S., Okeke, C.I.O., Nnamani, P.A., Obochi, E.C. \&Obasi, C.C. (2020). Relative effect of animated and non-animated powerpoint presentations on physics students' achievement. Cypriot Journal of Educational Science. 15(2), 00-00.

[25] Ugwuanyi, C.S., Ugwuanyi, C.C., Ezenwa-Nebife, D.C., Gana, C., Ene, C., Oguguo, B.C., Ikeh, F.E., Okeke, A.O., Nwoye, M.N., Obi, C.N., Anyaegbu, C. \& Agah, J.J (2019). Assessment of the efficacy of information and communication technology tool on achievement of students in physics and mathematics: A case of repeated measures. Journal of Engineering and Appli ed Sciences, 14(13), 4541-4546.

https://www.medwelljournals.com/ams/acceptance.php?i $\mathrm{d}=39579$

[26] Umar, F. (2012). Quantitative Economics study of mathematical concepts and Econometrics. Study lecture notes. www.studylecturenote.org. retrieved $24^{\text {th }}$ of October, 2019.

[27] West African Examination Council. (2013). Chief Examiner's Report. AbujaWest African Examination Council. 
International Journal of Engineering Research and Technology. ISSN 0974-3154, Volume 13, Number 6 (2020), pp. 1220-1230 (C) International Research Publication House. https://dx.doi.org/10.37624/IJERT/13.6.2020.1220-1230

[28] West African Examination Council. (2015). Chief Examiner's Report. Abuja: West African Examination Council.

[29] West African Examination Council. (2016). Chief Examiner's Report. Abuja: West African Examination Council.

[30] West African Examination Council. (2017). Chief Examiner's Report. Abuja: West African Examination Council.

[31] West African Examination Council. (2018). Chief Examiner's Report. Abuja: West African Examination Council. 